\title{
Self-Disclosure Sifat Independen Anak Tunggal pada Keluarga Broken Home
}

\author{
Dian Bagus Mitreka Satata \\ Magister Psikologi, Universitas Muhammadiyah Malang \\ dbagusms@webmail.umm.ac.id
}

\begin{abstract}
Broken home is a phenomenon in social life that occurs in family conflicts which can result in the child's personality development process. In the development of children, the family becomes a pillar in determining personality traits in adulthood. There is conflict in the family which results in a broken home, so a child has a different personality from a child whose parents are still intact. This study used a qualitative method of structured interviews through disclosure on the backgrounds of the children who were victims of broken homes, totaling five respondents. The findings reveal that children who are victims of broken homes expect to be more independent, with the attitude to be more comfortable interacting with other people or what they consider comfortable and activities outside the home than with their parents or one of their parents
\end{abstract}

Keywords: broken home, independent, only child, self-disclosure

\begin{abstract}
Abstrak
Broken home merupakan suatu fenomena dalam kehidupan sosial yang terjadi pada konflik keluarga yang dapat berakibat pada proses perkembangan kepribadian anak. Dalam perkembangan anak keluarga menjadi pilar dalam menentukan sifat kepribadian di masa dewasa. Adanya konflik di dalam keluarga yang berakibat pada broken home maka seorang anak memiliki kepribadian yang berbeda dengan anak yang orang tuanya masih utuh. Penelitian ini menggunakan metode kualitatif wawancara terstruktur melalui pengungkapan pada latar belakang anak korban broken home yang berjumlah lima responden. Hasil temuan mengungkapkan bahwa anak korban broken home berharap untuk bisa lebih hidup mandiri, dengan adanya sikap untuk lebih nyaman berinteraksi dengan orang lain atau yang dianggapnya nyaman serta kegiatan di luar rumah daripada kepada kedua orangtua atau salah satu dari orang tua mereka.
\end{abstract}

Kata kunci: anak tunggal, broken home, mandiri, pengungkapan diri 


\section{PENDAHULUAN}

Dalam suatu kehidupan tentu seorang individu mengalami suatu dinamika kehidupan yang kompleks. Dalam menunjang individu dalam menghadapi problem kehidupan keluarga merupakan tempat terbaik dalam bersosialisasi. Di dalam komponen keluarga terdapat ayah, ibu, adik, atau kakak (Aktar, 2013) yang membuat individu merasa nyaman untuk berinteraksi dengan sesama karena sudah saling mengenal satu sama lain, namun dalam keluarga yang ibarat tempat terbaik itu sendiri juga memiliki masalah tersendiri yang harus individu hadapi, salah satunya yaitu konflik yang berakibat pada tindak perbedaan pendapat sehingga terjadi perselisihan hingga perpecahan dalam anggota keluarga (Theobald et al, 2013).

Kasus perpecahan keluarga yang biasa disebut dengan perceraian keluarga berakibat fatal pada komponen keluarga lainnya, sehingga akan menimbulkan ketimpangan pada perilaku sosial khususnya anak (Anderson, 2014). Anak akan mengalami perubahan sikap dan mental ketika kedua orang tua mereka mengalami perceraian, terutama bagi anak yang tidak memiliki saudara atau tunggal. Namun biasanya anak yang memiliki latar belakang broken home memiliki mental yang kuat untuk lebih dalam bertahan hidup, tapi tidak sedikit pula yang kemudian minder atau merasa putus asa dalam keadaannya, karena keluarga merupakan sebuah unit dasar dalam masyarakat (Aktar, 2013).

Pada dasarnya sifat kemandirian dimiliki oleh setiap individu untuk bertahan hidup, terlepas dari manusia merupakan makhluk sosial. Mereka akan beradaptasi bagaimanapun caranya agar mampu untuk hidup tanpa merugikan orang lain. Pada beberapa contoh dari hasil penelitian sebelumnya menyebutkan bahwa kehidupan dalam keluarga orang tua tunggal atau keluarga yang berantakan dapat membuat stres baik bagi anak dan orang tua itu sendiri (Omoruyi, 2014).

Faktor-faktor lain juga berpengaruh pada kepribadian yang akan dibentuk seperti anakanak atau remaja yang menghadapi perceraian orang tuanya biasanya akan mengalami gejala gangguan kesehatan mental jangka pendek, yaitu stres, cemas, dan depresi (Wulandari \& Fauziah, 2019). Biasanya anak yang mengalami broken home akan mampu beradaptasi dengan lingkungan orang lain yang biasanya berbeda, hal ini pengaruh dari kondisi mental dan psikis yang dialami oleh anak yang merasa sebagai korban dari perceraian kedua orangtuanya (Damayanti \& Hayati, 2020).

Terlepas dari perbedaan-perbedaan ini, perceraian telah terbukti mengurangi kompetensi masa depan seorang anak di semua bidang kehidupan, termasuk hubungan 
keluarga, pendidikan, kesejahteraan emosional, dan kekuatan penghasilan masa depan (Anderson, 2014) namun semua itu dapat diubah ketika proses pendewasaan dan usia anak, karena memang semua itu memerlukan proses yang tidak cepat dalam hal perkembangan mental atau kepribadian anak. Proses ketahanan anak dimulai ketika sudah memasuki usia dewasa (Widyastuti, 2017), mereka bisa memilih apa yang mereka yakini untuk hidup kedepannya terlepas dari keadaan yang pernah dialami sebelumnya secara mandiri (Steinberg et al, 2004).

Hasil penelitian sebelumnya menemukan bahwa ketika anak-anak menyaksikan konflik antara orang tua mereka, ini akhirnya mengarah ke masalah di masa remaja mereka nantinya termasuk tingkat depresi dan kecemasan (Aktar, 2013; Damaryanti \& Hayati, 2020). Untuk lebih lanjut hasilnya nanti akan memungkinkan bahwa akan ada efek negatif jangka panjang dari pengalaman awal anak-anak ketika ada konflik antara orang tua mereka, seperti emosional mereka meningkat sebagai akibat dari konflik orang tua mereka (Nur, 2004). Selain itu akibat dari perceraian kedua orang tua dapat menimbulkan gejala sosial karena kelekatan dari kedua orangtua menjadi faktor penentu tingkat prososial pada anak untuk masa dewasa (Satata \& Saladin, 2020).

Ketika orang tua bercerai, biasanya salah satu dari mereka atau terkadang keduanya meninggalkan rumah. Maka kehadiran salah satu atau kedua orang tua akan mempengaruhi sistem dalam keluarga, maka keluarga akan menjadi rusak, hal tersebut berdampak pada keluarga itu sendiri terlebih menghancurkan anak-anak mereka (Saikia, 2017). Pada beragam permasalahan yang dialami oleh anak dalam keluarga yang broken home, masa setelah perceraian merupakan periode paling sulit bagi anak (Wulandri \& Fauziah, 2019).

Penelitian sebelumnya menemukan bahwa anak laki-laki yang tinggal di rumah orang tua tunggal menunjukkan lebih banyak agresi dan masalah dengan hukum daripada anak lakilaki dari keluarga utuh. Anak perempuan yang tinggal di keluarga dengan orang tua tunggal memiliki masalah yang lebih kompleks seperti agresi, pergaulan bebas, penggunaan narkoba dan masalah di lingkungan sekolah (Nareshkumar \& Ratnottar, 2005).

Perceraian berdampak buruk bagi masyarakat sosial terutama bagi anak mereka sendiri, seperti menurunkan kompetensi belajar anak kedepannya, melemahnya struktur keluarga, kontribusi orientasi seksual pada masyarakat, sisi religiusitas anak, menurunkan kemampuan belajar, serta menurunkan pendapatan rumah tangga karena akibat dari perceraian (Anderson, 2014 dan Widyastuti, 2017). Keluarga memiliki peran utama dalam mensosialisasikan anak- 
anak untuk menjadi anggota masyarakat yang produktif dan prososial (Theobald et al, 2013), namun ketika keluarga "hancur" atau tercerai berai maka proses sosialisasi dapat menjadi terganggu (Omoruyi, 2014).

Keluarga merupakan komponen terpenting dalam kehidupan sosial terutama bagi perkembangan anak, dan lagi rumah merupakan tempat tinggal yang layak untuk keluarga. Tidak ada seorang pun yang ingin kehilangan rasa aman bagi keluarganya, meskipun keluarga tersebut dalam kesulitan atau kesalahpahaman di dalamnya (Saikia, 2017). Hal ini didukung oleh faktor ketahanan internal dan eksternal pada seorang anak yang meliputi: penerimaan, religiusitas, kemampuan kognitif, kompetensi sosial, dan dukungan sosial (Widyastuti, 2017). Dalam hal ini, usia dewasa tampaknya menjadi faktor penting dalam mencapai ketahanan karena mencerminkan kematangan dalam faktor-faktor yang disebutkan sebelumnya.

Self-disclosure merupakan pengungkapan diri seseorang dalam mengungkap kejadian yang pernah dialaminya (Elaine et al, 2015). Berdasarkan pengalaman inilah maka selfdisclosure dapat menggambarkan dirinya melalui emosi positif atau negatif melalui curhat (bercerita) kepada orang lain yang dianggap nyaman. Namun biasanya dalam memberikan pengalaman yang menyakitkan atau dianggap dapat memberikan trauma psikologis seseorang lebih nyaman dalam mengungkapkan secara spontan. Maka hal tersebut orang-orang terdekat dan terpercaya yang menjadi media dalam memberikan gambaran kejadian negatif yang telah dialaminya (Rains et al, 2016).

Berdasarkan dari latar belakang masalah diatas maka dapat diketahui bahwa kehidupan seorang anak yang dijalani dengan kondisi orangtuanya bercerai atau broken home lebih sulit jika dibandingkan dengan seorang anak yang orangtuanya tidak bercerai. Maka tujuan dari penelitian ini adalah untuk mengungkap diri (self-disclosure) dari seorang anak akibat dari pasca perceraian kedua orangtuanya dan bagaimana anak menjadi seorang yang bersifat independen akibat dari perceraian kedua orangtuanya.

\section{METODE}

Penelitian ini menggunakan metode kualitatif wawancara fenomenologis yang bertujuan untuk mengungkap serta memahami fenomena konflik dalam keluarga yang unik dan dialami oleh individu atau seorang anak sebagai korban broken home. Dari pengalaman atau sebuah fenomena yang secara umum tidak biasa terjadi tersebut maka peneliti mencari 
perubahan sikap, sudut pandang atau perilaku pada responden yang mengalami pengalaman tersebut.

Responden dalam penelitian ini berjumlah lima responden, pemilihan responden dalam penelitian ditentukan dengan menggunakan teknik purposive sampling (Sugiyono, 2011). Berikut karakteristik responden pada tabel 1:

Tabel 1 .

Karakteristik responden

\begin{tabular}{lllll}
\hline Responden & Jenis Kelamin & Usia (tahun) & Status & Pekerjaan \\
\hline DAC & Perempuan & 23 & Lajang & Mahasiswa \\
FP & Perempuan & 26 & Lajang & Karyawan Swasta \\
TS & Perempuan & 28 & Lajang & Karyawan Swasta \\
AY & Laki-laki & 28 & Lajang & Wiraswasta \\
RH & Laki-laki & 29 & Lajang & Pegawai RS \\
\hline
\end{tabular}

Pengumpulan data pada penelitian ini menggunakan metode wawancara terstruktur. Responden diberikan informasi mengenai topik wawancara sesuai dengan latar belakang pengalaman responden sebelum memulai wawancara.

\section{Tinjauan Pustaka}

Broken home pada Keluarga

Keluarga sendiri merupakan kelompok terkecil dalam masyarakat (Saikia, 2017) yang beranggotakan ayah, ibu, dan anak. Aktar (2013) menjelaskan bahwa keluarga merupakan lembaga universal yang mencakup suami dan istri dengan atau tanpa anak. Definisi lain menjelaskan keluarga adalah unit sosialisasi utama dan dasar dan seorang anak belajar banyak perilaku, adat, tradisi, kepercayaan, norma, cerita rakyat, adat istiadat, kebiasaan, pola sosial, dan perilaku untuk hidup dalam keluarga (Qureshi, 2016).

Broken home atau yang biasanya kita kenal dengan keluarga yang bercerai merupakan konflik keluarga dimana terdapat ketidaksepahaman pendapat antara suami dan istri sehingga tidak dapat disatukan kembali. Perceraian berasal dari kata cerai yang artinya berpisah dan dikenal dengan istilah broken home. Broken home diartikan sebagai keluarga yang retak, yaitu kondisi hilangnya perhatian keluarga atau kurangnya kasih sayang dari orangtua yang disebabkan oleh beberapa hal, bisa karena perceraian sehingga anak hanya tinggal bersama satu orangtua kandung (Wulandri \& Fauziah, 2019)

Broken home memiliki banyak pengaruh dalam keluarga atau masyarakat sosial tentunya, namun dari semua itu akibat dari broken home sangat berdampak besar bagi anak 
karena sebagai korban langsung. Broken home membuat anak menjadi tidak aman karena tidak lengkapnya anggota keluarga (Saikia, 2017). Efek dari broken family kepada anak ini sangat banyak gangguan implikasi secara mental dan psikologis terutama, anak akan lebih memilih menyendiri dalam kehidupan sehari-harinya dan kurang bersosialisasi (Magpantay et al, 2014).

\section{Sifat Independen (Mandiri) Anak dari dampak Broken home}

Kemandirian atau sifat independen menurut Chaplin (2002) adalah kebebasan individu untuk memilih, untuk menjadi kesatuan yang bisa memerintah, menguasai dan menentukan dirinya sendiri. Dalam konsep Carl Rogers konsep independen sendiri merujuk pada istilah self (Desmita, 2012). Steinberg et al (2004) membedakan karakteristik independen atas tiga bentuk yaitu: 1) kemandirian emosional (emotional autonomy) yakni, perubahan kedekatan hubungan emosional anak dengan orangtua; 2) kemandirian tingkah laku (behavioral autonomy) yakni kemampuan membuat keputusan sendiri; dan 3) kemandirian nilai (value autonomy) yakni, prinsip tentang benar dan salah, tentang yang penting dan tidak penting.

Jadi sikap independen lebih memilih untuk bersikap mandiri dalam menjalankan tindakan apapun, tujuan dari sikap independen merujuk agar tidak ada salah satu pihak yang dirugikan atau mungkin tidak ingin dimenangkan jadi agar terkesan lebih adil. Kemandirian bertitik tolak pada paradigma yang menyatakan bahwa setiap individu atau kelompok bertanggung jawab atas kehidupannya sendiri, mengingat bahwa kita sebagai individu dilahirkan di dunia ini sendiri dan meninggal pun akan sendiri (Sa'diyah, 2017).

Sifat independen ditandai dengan kemampuan menentukan nasib sendiri, kreatif dan inisiatif, mengatur tingkah laku, bertanggung jawab, mampu menahan diri, mampu membuat keputusan sendiri, dan mampu mengatasi masalah tanpa ada pengaruh dari orang lain (Desmita, 2012). Erikson menyatakan independen adalah usaha untuk melepaskan diri dari orangtua dengan maksud untuk menemukan ego, yaitu perkembangan individu untuk ke arah yang mantap dan berdiri sendiri (Alwisol, 2008).

Perkembangan sifat independen memiliki tiga aspek, yaitu kemampuan berpikir abstrak lebih berdasarkan pada keyakinan personal terhadap prinsip-prinsip umum yang memiliki dasar ideologi (prinsip moral) dan menggunakan nilai-nilai individu sendiri dalam keyakinannya, bukan sistem nilai yang diturunkan oleh orang tua atau figur otoritas lainnya (Steinberg et al, 2004). Pada hasil penelitian Septia (2006) membuktikan bahwa seorang anak 
dari keluarga yang berstatus orang tua ayah cenderung memiliki tingkat kemandirian yang lebih tinggi daripada dari keluarga yang berstatus ibu tunggal.

\section{HASIL DAN PEMBAHASAN}

Berdasarkan analisis data menggunakan metode wawancara peneliti menemukan beberapa gambaran umum yang terjadi dari efek terjadinya konflik keluarga hingga terjadi broken home. Beberapa episode atau tahapan telah terbagi dari sikap anak sebelum terjadi broken home, sikap anak ketika terjadi broken home, dan sikap anak setelah keluarga broken home.

Dari kelima responden terdapat tiga perempuan dan dua laki-laki, sebagai berikut terdapat satu mahasiswa yaitu DAC yang merupakan responden perempuan termasuk FP dan TS namun kedua responden tersebut berstatus sebagai karyawan swasta. Terdapat dua responden laki-laki AY sebagai wiraswasta dan RH sebagai pegawai rumah sakit. Dimana semua responden ini merupakan keluarga yang awalnya hidup dalam keluarga yang utuh bersama kedua orangtua mereka, namun karena terdapat konflik yang terjadi pada kedua orang tua mereka maka terjadilah perceraian.

Kelima responden yang berusia antara 23 - 29 tahun dan merupakan korban broken home yang rata-rata merupakan anak tunggal dan tinggal tidak menetap sehingga ikut saudara dan hidup nomaden. AY merupakan anak laki-laki pertama yang memiliki adik perempuan yang duduk di bangku SMP saat ini, namun tidak disebutkan dalam proses wawancara. Pada kelima subjek ini terdapat hubungan dan pola asuh yang berbeda sebelum terjadinya broken home dan pasca broken home terjadi. Dalam pemilihan pola asuh responden dalam penelitian ini memihak antara kedua orang tuanya, namun mereka bimbang dalam menentukan untuk menetap pada siapa. Namun dari hasil wawancara diketahui mereka akhirnya memilih tinggal dari salah satu orangtuanya, atau bahkan tidak sama sekali.

TS lebih memilih ayah karena dianggap mampu dalam memenuhi kebutuhan hidupnya, namun saat ini tinggal bersama bibinya, namun TS berharap ada keinginan untuk mandiri dengan cara sewa rumah atau nge-kos sendiri untuk lebih hidup mandiri dan bebas. Sedangkan RH lebih memilih untuk ikut pakde (kakak dari salah satu orang tuanya) karena ayahnya sudah tidak pernah mengurus dia lagi, namun sebelumnya lebih cenderung kepada ibunya. RH lebih banyak menghabiskan waktu bersama saudara dan orang lain daripada orangtuanya, terlihat dari hasil wawancara yang selalu nomaden saat SMP, SMA, hingga kuliah. 
AY dan DAC cenderung untuk memilih untuk berpihak kepada ibunya karena AY beranggapan bahwa kasih ibu lebih besar daripada ayah. TS dan FP lebih cenderung memilih untuk berpihak pada ayah karena terdapat unsur dalam pemenuhan kebutuhan yang masih bisa dipenuhi dari ayah. Sedangkan RH tidak memihak pada siapapun karena lebih hidup nomaden dan sering ikut saudaranya, sehingga pola asuh orangtua menurut $\mathrm{RH}$ sudah hilang, namun pada TS karena figur seorang ibu yang sudah berkeluarga lagi dan hidup bersama orang lain maka hak asuh ibu menurut TS hilang dan lebih memilih ayah yang lebih bertanggung jawab.

Kelima responden ini bingung menentukan arah dan tujuan mereka, namun karena dari masing-masing memiliki sikap maka mereka cenderung untuk lebih memilih hidup mandiri ke depannya. Mereka harus menyesuaikan kembali kehidupan mereka pasca terjadinya broken home, karena pola asuh yang berbeda dari awal hingga perubahan yang terjadi. Responden akhirnya lebih banyak menghabiskan waktu bersama orang lain seperti saudara, teman-teman, pembantu, bahkan nongkrong hingga larut.

Namun dibalik semua itu ada kecenderungan iri dengan teman-teman yang lain sehingga terjadilah konflik batin antara kejadian sebelumnya dengan sikap yang diambil. Munculnya emosi merupakan hal wajar dalam menyikapi peristiwa yang terjadi, seperti harus memilih siapa yang harus menjadi figur tanggung jawab yang pantas sebagai orangtua mereka, seperti RH yang beranggapan agar adil akhirnya tidak berpihak kepada kedua orangtuanya dalam kehidupan sehari-hari.

Untuk DAC yang mungkin masih dibilang labil, dia lebih memilih ibunya namun ada kecenderungan untuk ke ayahnya, karena faktor kebutuhan yang harus dipenuhi sebagai mahasiswa, sedangkan ibunya sendiri juga terkadang sibuk oleh pekerjaan sehingga tidak waktu bersama. Berbeda dengan TS yang ikut figur ayah karena paksaan dari ayahnya sendiri untuk hidup bersamanya. Namun dari semua kejadian rata-rata orangtua masih bisa dihubungi dan ditemui oleh masing-masing responden, kecuali TS yang ibunya sudah memiliki keluarga sendiri.

Reaksi dari kelima responden ini terlihat bahwa sifat independen muncul seiring waktu berjalan, dari masing-masing terlihat bahwa harapan mereka untuk tidak bergantung pada kedua orang tua yang mengalami konflik tersebut. Karena latar belakang mereka yang akhirnya dititipkan saudara seperti yang dialami RH atau kesibukan orangtua mereka seperti yang dialami TS dan DAC sehingga mereka melampiaskan dengan curhat (bercerita) pada orang lain 
yang dianggap lebih nyaman. Perlu waktu untuk beradaptasi dengan hal yang baru dengan keadaan yang tidak stabil, maka hal ini disebut dengan resiliensi (Altundağ \& Bulut, 2014).

Tingkat resiliensi dan motivasi dari responden sangat tinggi dalam menghadapi masalah, namun masih terdapat faktor-faktor yang dapat membuat perubahan psikologis seperti perasaan stres (Widyastuti, 2018) yang dialami oleh FP dan TS mereka merasakan stres ketika terjadi konflik yang berlangsung. Namun dari kelima responden tidak memiliki efek negatif signifikan seperti perilaku menyimpang (Aktar, 2013), karena tingkat religiusitas dan konsep diri yang kuat maka responden memiliki sikap yang positif kuat dan memotivasi dirinya sendiri.

Terdapat tingkat religiusitas dari partisipan dari DAC "bahwa ini adalah kehendak Allah..." sehingga DAC mampu memotivasi diri ke arah yang baik. Religiusitas merupakan pemahaman seseorang terhadap agama dan tingkat komitmen terhadap agamanya (Wulandri \& Fauziah, 2019). Dari semua kejadian tersebut tergantung pada tingkat kematangan dan emosional bagaimana cara menyikapi pada tiap-tiap individu (Naresh Kumar \& Ratnottar, 2005) seperti TS, FP yang lebih humanis dan dekat kepada teman-temannya.

Pada setiap permasalahan memiliki makna tersendiri bagi tiap-tiap responden, namun bagaimana sikap dalam menghadapi setiap kejadian yang sudah terjadi seperti AY yang meski iri dengan teman lainnya dia bersikap "tetap menerima kejadian dan perbedaan yang dilalui dan terus maju". Untuk responden RH mampu untuk bertahan dengan kejadian yang sudah dilaluinya hingga saat ini, dan bersikap untuk tidak terjadi pada anaknya kelak seperti yang diungkapkan “...Jangan sampai anakku nanti seperti aku nasibnya”.

Responden inisial TS mampu untuk memutuskan apa yang akan dikerjakan sendiri tanpa ada kendala dari kejadian sebelumnya sehingga percaya diri serta mandiri, seperti yang diungkapkan “...sekarang saya bisa menentukan keputusan saya sendiri apa yang saya mau”. Untuk FP lebih bersikap netral dan tidak bergantung pada siapapun “...Saya mencoba bersikap netral dan tidak memihak kepada siapa-siapa kecuali kalau mereka mau balik lagi, itu harapannya si". Responden berinisial DAC memiliki sikap untuk terus mandiri dalam menghadapi masalah yang dihadapinya saat ini seperti yang diungkapkan sebagai berikut “...tapi saya sendiri harus mandiri kak, biar mama gak kepikiran aku terus, kayak gitu sih”.

Berdasarkan analisis data dan wawancara dengan partisipan, peneliti menemukan tiga alur kejadian yaitu sebelum broken home, saat broken home, setelah broken home, yang masing-masing memuat beberapa tema yang dirangkum pada tabel 2 sebagai berikut: 
Tabel 2.

Alur kejadian dan tema secara umum

\begin{tabular}{lll}
\hline Kejadian & Tema & \\
\hline Sebelum Broken home & 1. & Informasi korban terhadap konflik orangtua \\
& 2. & Hubungan dengan orangtua \\
& 3. & Kehidupan sosial \\
& 4. & Pola asuh orangtua \\
Saat Broken home & 5. & Makna ayah dan ibu (orangtua) \\
& 1. & Kondisi terjadi konflik - broken home \\
& 2. & Akibat dari broken home \\
& 3. & Dukungan keluarga \\
& 4. & Perubahan tatanan dalam keluarga \\
& 5. & Muncul emosi negatif \\
& 6. & Kondisi psikologis \\
\hline Setelah Broken home & 7. & Perubahan yang dialami \\
& 1. & Penerimaan diri \\
& 2. & Motivasi intrapersonal \\
& 3. & Harapan ke depan \\
& 4. & Muncul sikap mandiri (independen) \\
\hline
\end{tabular}

Pada pernyataan responden telah ditemukan sikap percaya diri dan kemandirian dari setiap masalah yang dialami. Sikap mandiri ditemukan pada beberapa pernyataan pada kelima responden sehingga dapat ditarik kesimpulan bahwa dari korban broken home menimbulkan sifat independen dan tidak memihak pada salah satu kedua orangtua, karena riskan dengan konflik yang terjadi selanjutnya. Pada beberapa pernyataan mengenai ikut dengan salah orangtua pada responden masih ada, namun mereka berharap kedepan lebih bisa hidup mandiri tanpa bergantung pada kedua orang tua yang sudah broken atau salah satu.

\section{SIMPULAN}

Dari data yang didapat melalui wawancara ditemukan bahwa anak yang menjadi korban broken home pada akhirnya memiliki penyimpangan kepribadian dan perubahan sikap, akibat dari perceraian anak mengalami gangguan kesehatan mental serta kesejahteraan. Hasil menunjukkan tingkat resiliensi yang muncul akibat dari perceraian orangtua. Munculnya sikap tersebut ditandai dengan sikap independen atau tidak memihak pada kedua atau salah satu orangtua mereka pasca perceraian. Responden berharap untuk tidak sampai terjadi lagi hal serupa pada dirinya apabila menjadi orangtua bagi anak-anaknya kelak. Sikap independen dari masing-masing responden mampu menguatkan bahwa sifat independen mampu memberi pengaruh positif pada kehidupannya di masa depan. 
Keterbatasan dalam penelitian ini adalah peneliti sibuk bekerja dan kurangnya pengungkapan diri secara keseluruhan pada latar belakang keluarga masing-masing responden. Maka saran untuk penelitian selanjutnya lebih menekankan wawancara pada latar belakang keluarga sehingga lebih akurat untuk mendalami secara emosi dan faktor psikologis anak dari korban broken home.

\section{DAFTAR PUSTAKA}

Aktar, S. (2013). Effects of family breakup on children: a study in khulna city. Bangladesh E-Journal of Sociology, 10(1), 138-152.

Altundağ, Y., \& Bulut, S. (2014). Prediction of resilience of adolescents whose parents are divorced. Psychology, 5(10), 1215-1223. https://doi.org/10.4236/psych.2014.510134

Alwisol. (2008). Psikologi Kepribadian. Malang. UMM Press.

Anderson, J. (2014). The impact of family structure on the health of children: effects of divorce.
Linacre
Quarterly,
81(4),
$378-387$.

https://doi.org/10.1179/0024363914Z.00000000087

Damaryanti, F.A., \& Hayati. (2020). Sikap kemandirian pada dewasa awal anak korban perceraian. JP3SDM, 9(2), 54-68.

Desmita. (2012). Psikologi Perkembangan Peserta Didik, Panduan bagi Orangtua dan Guru dalam Memahami Psikologi Anak Usia SD, SMP, dan SMA. Remaja Rosdakarya.

Harcourt, P. (2018). Comparative study of academic performance of students from broken and intact homes in biology in omuma local government area of rivers state. European Journal of Research and Reflection in Educational Sciences, 6(2), 40-47.

Magpantay, Joyce, M., Malabrigo, Precious, Malijan, Joseph, R.., \& Gayrose. (2014). Behavioral problems and coping strategies of selected adolescents belonging to a broken family. CAM Research Journal, 2(1), 112-135.

Mi, Y., Bian, C., Wan, J., Yao, C., \& Li, C. (2017). Modular solid-state nanosecond pulse generator based on blumlein and transmission line transformer. Yi Qi Yi Biao Xue Bao/Chinese Journal of Scientific Instrument, 38(11), 2858-2865.

Mooney, A., Oliver, C., \& Smith, M. (2009). Impact of family breakdown on children's wellbeing: evidence review. Research Report DCSF-RR 113, 4-24. Retrieved from http://eprints.ioe.ac.uk/3037/ 
Nareshkumar, A., \& Ratnottar. (2005). Humanities and social emotional maturity among intact and broken home adolescents. Journal of Information, Knowledge and Research in Humanities and Social, 3(2), 146-148.

Nur. M.F. (2004). Dinamika emosi pada remaja dari keluarga yang bercerai. Jurnal Psikosains, $9(2), 101-112$

Omoruyi, V. (2014). Influence of broken homes on academic performance and personality development of the adolescents in lagos state metropolis. European Journal of Educational and Development Psychology, 2(2), 10-23. Retrieved from www.eajournals.org

Qureshi, A. (2016). Socio psychological effects of broken families on socialization and academic performance among the children of multan division. International Journal of Innovation and Scientific Research, 22(1), 146-152.

Rains, S. A., Brunner, S. R., \& Oman, K. (2016). Self-disclosure and new communication technologies: the implications of receiving superficial self-disclosures from friends. Journal of Social and Personal Relationships, 33(1), 42-61. https://doi.org/10.1177/0265407514562561

Renee Wilson-Simmons, Yang jiang, Y. aratani. (2008). Strong at the broken places : the resiliency of low-income parents. National Center for Children in Poverty, 83(2), $243-$ 250.

Satata, D.B.M., \& Saldin, M. (2020). Perbedaan jenis kelamin sebagai moderasi hubungan attachment parenting dengan perilaku prososial pada remaja. Jurnal Fenomena, 29(1), 27-32. DOI: 10.30996/fn.v29i1.3680

Sa'diyah, R. (2017). Pentingnya melatih kemandirian anak. Kordinat, 15(1), 31-46.

Saikia, R. (2017). Broken family: its causes and effects on the development of children. International Journal of Applied Research, 3(2), 445-448.

Sillekens, S., \& Notten, N. (2018). Parental divorce and externalizing problem behavior in adulthood. a Study on lasting individual, family and peer risk factors for externalizing problem behavior when experiencing a parental divorce. Deviant Behavior, 0(0), 1-16. https://doi.org/10.1080/01639625.2018.1519131

Steinberg, Laurence \& Lerner, Richard M. (2004). Handbook of Adolescent Psychology (2 Edition). New Jersey: John Willey \& Sons Inc 
Theobald, D., Farrington, D. P., \& Piquero, A. R. (2013). Childhood broken homes and adult violence: An analysis of moderators and mediators. Journal of Criminal Justice, 41(1), 44-52. https://doi.org/10.1016/j.jcrimjus.2012.12.003

Widyastuti, T. (2018). Resilience of a child from a broken-home family: a phenomenology study. Ijasos.ocerint journals, https://doi.org/10.18769/ijasos.370052

Wulandari, D., \& Fauziah, N. (2019). Pengalaman remaja korban broken home (studi kualitatif fenomenologis). Empati, 8(1), 1-9. 